\title{
Empirical Analysis of Firm Attributes before and after the Sarbanes-Oxley Act
}

\author{
Pennye K. Brown ${ }^{1} \&$ Dong Y. Nyonna ${ }^{1}$ \\ ${ }^{1}$ Acounting, Finance, and Economics Department, Austin Peay State University, Clarksville, USA \\ Correspondence: Pennye K. Brown, Accounting, Finance, and Economics Department, Austin Peay State University, \\ 601 College Street, Clarksville, TN 37044, USA. Tel: 931-221-7755. E-mail: brownp@apsu.edu
}

Received: January 5, 2015

Accepted: January 29, 2015

Online Published: April 17, 2015

doi:10.5430/ijfr.v6n2p139

URL: http://dx.doi.org/10.5430/ijfr.v6n2p139

\begin{abstract}
This paper examines whether voluntary delisting from U. S. exchanges by international firms surged during the five years following the passage of Sarbanes-Oxley ACT of 2002 (SOX). Using 278 international firms, which include 139 delisted international firms from NYSE and NASDAQ and a matched pair of 139 non-delisted international firms, we document that the number of voluntary delisting increased significantly from $12.9 \%$ in the pre-SOX period $(1997-2001)$ to $87.1 \%$ in the post-SOX period $(2002-2007)$. This represents an increase of $74.2 \%$ in the number of international firms that delisted. In addition, using a predictive model advanced by Piotroski and Srinivasan (2008) and Doidge, Karolyi, and Stulz (2009), we find that yearly profitability ratio is negatively affected by ADR listing status and is the strongest predictor of delisting in the logistical regression model. Furthermore, firm size, corporate governance and leverage ratio are not statistically significant in predicting ADR listing status or associated with SOX legislation. This supports the documented evidence that the SOX legislation did not decrease or negatively affect firm size, corporate governance, or leverage ratio.
\end{abstract}

Keywords: cross-listed, delisted, international firms, SOX legislation

\section{Introduction and Previous Studies}

It is often argued that international firms cross-list their shares on U. S. exchanges to take advantage of the so-called bonding and signaling hypotheses. Karolyi (1998) notes that the most natural vehicle to obtain equity financing by international firms is to list their shares on a major stock exchange. As a result, by the mid-1990s, international firms from more than 40 countries were listed on U. S. stock exchanges. However, following the enactment of the SOX, studies on the benefits of international firms cross-listing on U. S. exchanges document mixed results.

As with previous legislations, the passage of SOX generated tremendous amount of research interests among academia and practitioners alike. Among the theories explaining the reasons international firms cross list their shares on U. S. exchanges, the signaling and bonding theories are worth mentioning. The Brealey, Leland, and Pyle's (1977) signaling or information disclosure theory asserts that firms that list on exchanges with stringent listing and disclosure requirements signal to investors their credibility and willingness to be transparent. In support of the signaling theory, Ying, Lewellen, Schlarbaum, and Lease (1977) note that investors interpret the listing application as a credible signal that serves as a reliable expression of managerial confidence in the future prospects of the firm. Consequently, the signaling theory suggests firm value will be enhanced if cross-listed on U.S. exchanges.

Using a sample of 4452 firms, Lang, Lins, and Miller (2003) examine whether cross listing in the U.S. improves an international firm's information environment and find support for the hypothesis that non-U.S cross-listed firms have better information environments, and consequently, higher market valuations. In one of the earliest studies of stock price activity, Ule (1937) analyzes stock returns on all stocks listed on the NYSE from 1934 to 1937 and document an abnormally large stock returns surrounding the listing event. This result is consistent with the signaling hypothesis. Similarly, Alexander, Eun, and Janakiramanan (1988) analyze 34 international cross listed firms from 1969 to 1982 and find a $12 \%$ abnormal return.

Pioneered by Coffee (1999), the bonding theory asserts that a U.S. listing of international firms serves as a bonding mechanism by which executives of international firms are bonded to operate with transparency, and as such minority shareholders will not be exploited. Using a sample of 714 cross-listed international firms and 4,078 non cross-listed 
firms from 40 countries, Doidge, Karolyi, and Stulz (2004) find that cross-listed international firms have a higher valuation (as measured by Tobin's q) than non-cross listed international firms. As further support for the bonding hypothesis, they document that voting premiums are $43 \%$ higher for U.S. cross-listed international firms than for firms that do not list in the United States. In addition, Piotroski and Srinivasan (2008) argue that SOX legislation should strengthen the credibility of U.S. listing as a bonding mechanism and thus potentially increase the expected benefits from a U.S. listing.

On the contrary, Georgieva (2009) asserts that the implementation of SOX has shifted the bonding benefits for international firms. In another study, Licht (2004) suggests the large increase in compliance costs experienced by international firms has dissipated the benefits gained from listing in the United States and undermined the bonding hypothesis. Additionally, Cardenas (2009), Krishnan, Rama, and Zhang (2008), and Zhang (2007) document that SOX compliance costs eroded firm valuations and motivated them to delist from U. S. exchanges. Other studies suggest the increased costs of complying with SOX outweigh the benefits of both the signaling and bonding theories (Doidge, Karolyi, \& Stulz, 2010; Fernandes, Lel, \& Miller, 2010; and Litvak, 2007). Furthermore, Doidge et al. (2009) find that listing preferences of large international firms did not change following the enactment of SOX.

Most of these studies investigated the listing choices of international firms between U. S. exchanges (NYSE \& NASDAQ) and the London Stock Exchange (LSE) before and after the passage of SOX. However, cross-listing in the U.S. is not only limited to firms from the U.K., but also to firms from around the world. As a result, our study bridges this gap by including in the analysis, cross-listed firms from other countries as well as the U.K.

Thus the purpose of this study is to assess whether passage of Sarbanes Oxley Act of 2002 (SOX) legislation had an impact on executives of international firms voluntarily requesting to leave the New York Stock Exchange (NYSE) and the National Association of Securities Dealers Automated Quotations (NASDAQ) from 1997 through 2007. SOX established new accountability standards for U.S. publicly traded companies and embedded objectives for protecting shareholders' rights, preventing corruption, and making investing safer.

Our paper focuses on the predictability of voluntary delisting of international firms before and after the enactment of SOX. In selecting a control sample, previous studies employ a matching procedure based on industry. Because we are analyzing firm attributes of international firms, we think an appropriate method of selecting a control sample is to use a one-to-one matching procedure based on home country rather than industry.

Using a sample of 278 international firms (139 delisted international firms from NYSE or NASDAQ and a matched pair of 139 non-delisted international firms), we document a significant increase of $74.2 \%$ in the number of voluntary delisting from the pre-SOX period $(1997$ - 2001) to the post-SOX period $(2002$ - 2007). In addition, using a predictive model advanced by Piotroski and Srinivasan (2008) and Doidge et al. (2009), we find that yearly profitability ratio is positively affected by ADR listing status and is the strongest predictor of delisting in the logistical regression model. Furthermore, firm size, corporate governance, and leverage ratio are not statistically significant in predicting ADR listing status or associated with SOX legislation. This supports the documented evidence that the SOX legislation did not decrease or negatively affect firm size, corporate governance, or leverage ratio.

The rest of the study proceeds as follows. Section 2 states the hypotheses while section 3 discusses data and methodology. The empirical results are represented in section 4, and section 5 concludes the paper.

\section{Hypotheses}

Despite arriving at contradictory conclusions, researchers agree that SOX legislation has had an impact on the U.S. capital markets. For example, a number of studies speculate SOX legislation caused an increase in the number of international firms delisting from U.S. stock exchanges (Hansen, Pownall, and Wang, 2009; Nordberg, 2008; and Piotroski and Srinivasan, 2008). Compliance with SOX legislation creates increased costs for listed firms (Note 1), therefore, we will expect the bottom line of some listed firms to dwindle thus motivating them to delist. Consequently, our first hypothesis follows.

Hypothesis 1: We expect a positive relationship between the probability of delisting and the passage of SOX. In other words, we expect an increase in the number of delisted international firms following the enactment of SOX.

Financial ratios have long been regarded as useful signals of corporate health because they provide quantitative information about company performance and its future prospect of profitability to investors, analysts, creditors, and competitors within its industry over time (Wahlen, Stickney, Brown, Baginski, \& Bradshaw, 2011). In support of that, Gibson (2011) notes that no other tool is more effective in evaluating the financial health of a company and 
projecting its financial future than financial ratios. Over the years, empirical studies have consistently demonstrated the usefulness of financial ratios (Chen \& Shimerda, 1981).

As mentioned previously, SOX legislation has increased costs, thereby changing the cost structure and profitability of a firm (Asthana Balsam, and Kim, 2009; Holmstrom \& Kaplan, 2003). Costs of achieving SOX compliance are borne by all publicly traded firms on the American markets (Anand \& Tarantino, 2010). Certainly, the implementation of any major legislation comes with costs.

Furthermore, Linck, Netter, \& Yang (2009) document that following the passage of SOX, director and officer insurance premiums doubled, audit committee costs increased, and the composition of the board members changed to include more highly compensated lawyers, management consultants, and financial experts. Asthana et al., (2009) quantified these additional SOX compliance costs to average approximately $0.10 \%$ of revenues. The magnitude of these increased compliance costs imposed by SOX legislation dilutes profitability. Thus our second hypothesis follows:

Hypothesis 2: In view of the increased cost of compliance imposed by SOX legislation, we expect a significant decline in profitability for voluntary delisted firms after the passage of SOX.

Saudagaran (1988) examines prelisting and post-performance characteristics to determine which market factor has the greatest degree of significance on listing decisions by executives of international firms. The study finds that the relative size of a firm in its domestic capital market and the proportion of foreign sales to total assets are the most influential factors affecting executives' decision to list shares abroad.

Piotroski and Srinivasan (2008) and Doidge et al. (2009) employ firm size as a predictor in their respective models, and find that listing preferences of large international firms do not change following the enactment of SOX legislation. However, both studies document a noticeable change in listing preferences by small international firms. Piotroski and Srinivasan conclude that smaller, less profitable firms choose to list on the London Alternative Investment Market (AIM). This change in listing preference represents a negative effect among small international firms, which is consistent with the incremental costs associated with SOX compliance. Hansen et al. (2009) add support by stating that firm size is significantly negatively associated with SOX legislation. In view of the documented empirical evidence on firm size and the passage of the SOX legislation, we think international firms that delisted after SOX are relatively small compared to their counterparts in the control sample. Therefore our hypothesis on the relationship between firm size and SOX legislation is the following.

Hypothesis 3: Firm size for voluntary delisted firms is expected to fall after the passage of SOX.

As noted earlier, a newly imposed requirement by SOX compliance causes listed firms to incur additional costs that include fees paid for independent audits of internal controls over financial reporting (Cárdenas, 2009; Krishnan et al., 2008; I. X. Zhang, 2007). Block (2004) surveyed 110 firms that went private between January 2001 and July 2003, and document that, on average, the cost of being public after SOX legislation went from $\$ 900,000$ to just short of $\$ 2$ million.

International firms that delisted following the implementation of SOX will have weaker corporate governance structures since they will avoid the scrutiny of independent audits and highly compensated lawyers on the board of directors. In support of that, Piotroski and Srinivasan (2008) notes that markets with less restrictive listing requirements attract firms employing a low-quality auditing firm. Hence we formulate our hypothesis on corporate governance as:

Hypothesis 4: After the passage of SOX, we expect voluntary delisted firms to have weaker corporate governance structures than the pre-SOX period.

Studies show that the direct and indirect costs of SOX compliance tend to motivate executives of firms to take actions, such as going private, to avoid SOX legislation. Gleason, Payne, and Wiggenhorn (2007) apply a multivariate analysis to a sample of 221 firms that went private between 1998 and 2003 along with a control sample of 221 firms and document among other findings that firms that went private had a greater chance of financial distress, smaller size, and more financial leverage. Consequently, we have no reason to assume on the contrary, and so, our last hypothesis follows.

Hypothesis 5: We expect an increase in leverage for voluntary delisted firms following the passage of SOX. 


\section{Data and Methodology}

\subsection{Sample}

A total of 465 international firms that met the definition of voluntary delisting from the NYSE and NASDAQ and simultaneously deregistered with the SEC by filing a Form 15 were identified as candidates for our sample. Out of that, 301 firms were removed from the sample because they consisted of firms from countries that did not use American Depository Receipts (ADRs) as a listing mechanism. In addition, 25 firms with missing financial information or did not have a matched-pair firm from the same country were excluded, leaving us with 139 voluntarily delisted international firms.

For robustness we match each firm in our sample with an international cross-listed firm by country and firm size (market capitalization) from 1997 through 2007. For each firm in our sample we first match by country. Next, we obtain data on market capitalization from the Center for Research into Securities Prices (CRSP) for all firms in our sample and the control sample.

We follow the technique of Ule (1937), Huang and Stoll (1996), and Gleason et al. (2007) and calculate a matching score for each firm using our entire sample of firms. The matching score, MSCORE is given by the expression:

$$
\text { MSCORE }=\left[\frac{X^{I}-X^{C}}{\left(X^{I}+X^{C}\right) / 2}\right]^{2},
$$

where $X$ depicts market capitalization, $I$ represents a firm in the delisted sample, and $C$ depicts a firm in the control (non-delisted) sample. Then for each international cross-listed firm in our sample, we select a control firm with the smallest MSCORE. This matching procedure produces a control sample of 139 non-delisted international cross-listed firms.

Matching each delisted and non-delisted international firm according to home country captures the unique characteristics of the country including size of the government of the country, as well as legal structure, monetary and banking policy, international trade, and regulatory requirements of the country. Separating home country characteristics provide internal validity to the results.

\subsection{Sources of Data}

International firms that wish to cross-list their shares on American stock exchanges do so as American Depository Receipts (ADRs). As a result, we obtain data on ADRs from the websites of U.S. depository bank, Bank of New York Mellon (BNYM), the Securities and Exchange Commission (SEC), Center for Research into Security Prices (CRSP), and Mergent online databases. The BNYM website provides the most complete information on ADRs for all depository banks and all U.S. stock exchanges. The SEC website is the primary source to identify international firms that use ADRs as a listing vehicle. Data were cross-referenced with the BNYM website from the same period. Members of the delisted group were identified from the CRSP database. The Mergent Online database provide data for all variables by year, which was used to distinguish the characteristics of the delisted and non-delisted firms by type of listing, and the data obtained were cross referenced with the SEC database.

To construct the analysis, a complete list of all active ADRs on the NYSE and NASDAQ for the years 1997 through 2007 was identified by listing year. All ADR firms were categorized as either non-delisted or delisted. Delisted companies were ascribed a code of 1 and non-delisted firms were ascribed a code of 0 . Even though there are four levels of ADRs, we use only levels II and III in our study. (Note 2) Level I (trade over the counter) and Level IV ADRs (private placement) were excluded because they are not subject to SOX regulation.

\subsection{Summary Statistics}

Table 1 reports the distribution of the 278 (both the delisted and non-delisted) international firms on NYSE and NASDAQ from 31 countries for our study period, 1997 through 2007. The United Kingdom represents the highest number of delisted firms (30) in the study when compared to other countries. 
Table 1. Country count and percent statistics by ADR listing status

Here, we report both the number of delisted and non-delisted cross-listed international firms by country.

\begin{tabular}{|c|c|c|c|c|}
\hline \multirow[b]{3}{*}{ Country } & \multicolumn{4}{|c|}{ ADR Listing Status } \\
\hline & \multicolumn{2}{|c|}{ Nondelisted } & \multicolumn{2}{|c|}{ Delisted } \\
\hline & Count & $\begin{array}{l}\% \text { within } \\
\text { country }\end{array}$ & Count & $\begin{array}{c}\% \text { within } \\
\text { country }\end{array}$ \\
\hline Australia & 6 & 50 & 6 & 50 \\
\hline Belgium & 1 & 50 & 1 & 50 \\
\hline Bermuda & 6 & 50 & 6 & 50 \\
\hline British Virgin Islands & 1 & 50 & 1 & 50 \\
\hline Cayman Islands & 4 & 50 & 4 & 50 \\
\hline Denmark & 1 & 50 & 1 & 50 \\
\hline Finland & 1 & 50 & 1 & 50 \\
\hline France & 14 & 50 & 14 & 50 \\
\hline Germany & 11 & 50 & 11 & 50 \\
\hline Greece & 1 & 50 & 1 & 50 \\
\hline Hong Kong & 2 & 50 & 2 & 50 \\
\hline Ireland & 3 & 50 & 3 & 50 \\
\hline Israel & 10 & 50 & 10 & 50 \\
\hline Italy & 4 & 50 & 4 & 50 \\
\hline Japan & 5 & 50 & 5 & 50 \\
\hline Korea & 2 & 50 & 2 & 50 \\
\hline Liberia & 1 & 50 & 1 & 50 \\
\hline Luxembourg & 4 & 50 & 4 & 50 \\
\hline México & 1 & 50 & 1 & 50 \\
\hline Netherlands & 14 & 50 & 14 & 50 \\
\hline New Zealand & 1 & 50 & 1 & 50 \\
\hline Norway & 1 & 50 & 1 & 50 \\
\hline Perú & 1 & 50 & 1 & 50 \\
\hline Portugal & 1 & 50 & 1 & 50 \\
\hline Singapore & 3 & 50 & 3 & 50 \\
\hline South Africa & 2 & 50 & 2 & 50 \\
\hline Spain & 2 & 50 & 2 & 50 \\
\hline Sweden & 2 & 50 & 2 & 50 \\
\hline Switzerland & 3 & 50 & 3 & 50 \\
\hline Taiwan & 1 & 50 & 1 & 50 \\
\hline United Kingdom & 30 & 50 & 30 & 50 \\
\hline
\end{tabular}

Table 2 depicts descriptive statistics for the independent variables, firm size, leverage ratio, and yearly profitability ratio, in the study. We use total assets as a proxy for firm size. As reported on the table, total assets of the delisted international firms range from $\$ 4,658$ to $\$ 2.155$ billion, with a mean of $\$ 40.330$ million. In contrasts, total assets of the non-delisted international firms range from $\$ 22,289$ to $\$ 24.1$ billion, with a mean of $\$ 403.8$ million. Clearly, on average, the non-delisted firms are larger than their delisted counterparts, adding support to our third hypothesis. 
Table 2. Independent variable descriptive statistics by ADR listing status

This table reports descriptive statistics on our quantitative independent variables: Firm Size (Total Assets), Leverage Ratio, and Profitability Ratio.

\begin{tabular}{llrcc}
\hline ADR & Statistic & \multicolumn{1}{c}{ Total assets } & Leverage & Profitability \\
\hline Nondelisted & Mean & $\$ 403,856,771.99$ & 0.54 & 0.03 \\
& $S D$ & $\$ 2,481,762,128.43$ & 0.26 & 0.17 \\
& Minimum & $\$ 22,289.00$ & 0.00 & -0.94 \\
\multirow{5}{*}{ Delisted } & Maximum & $\$ 24,126,885,000.00$ & 1.01 & 0.41 \\
& Mean & $\$ 40,330,117.61$ & 0.59 & -0.16 \\
& SD & $\$ 241,020,520.59$ & 0.34 & 0.68 \\
& Minimum & $\$ 4,658.00$ & 0.00 & -5.49 \\
& Maximum & $\$ 2,154,837,000.00$ & 2.18 & 0.49 \\
\hline
\end{tabular}

Next, we represent leverage ratio by total debt to total assets. The leverage ratio for delisted international firms is in the range of 0.00 to 2.18 , with a mean leverage ratio of 0.59 and a standard deviation of 0.34 . For the non-delisted international firms, the range is 0.00 to 1.01 , with a mean leverage ratio of 0.54 and a standard deviation of 0.26 . The last column of Table 2 reports summary statistics for profitability ratio (net income to total assets). The delisted international firms' profitability ratio ranges from -5.49 to 0.49 , with a mean yearly profitability ratio of -0.16 . The profitability ratios of non-delisted international firms are ranged from -0.94 to 0.41 , with a mean yearly profitability ratio of 0.03 . This indicates on average, the non-delisted international firms are more profitable than the delisted international firms in the sample period.

Descriptive statistics for the fourth independent variable, corporate governance (captured as a nominal variable), are reported in Table 3. Using our criterion for high- versus low-quality audit firms (discussed below in the explanation of variables), 33 of the 139 (or $23.7 \%$ ) delisted international firms have high governance standards while 24 of the 139 (or 17.3\%) non-delisted international firms have high governance standards. The statistics indicate that corporate governance for both the delisted and non-delisted international firms in the sample period appears to be similar. This leads to the assertion that corporate governance is negatively associated with ADR listing status scaled by the quality of the audit services, based on the size of the audit firm.

Table 3. Corporate governance count and percent statistics by ADR listing status

The table depicts descriptive statistics on our categorical independent variable, corporate governance.

\begin{tabular}{lllc}
\hline \multirow{2}{*}{ ADR status } & Statistic & \multicolumn{2}{c}{ Governance quality } \\
\cline { 3 - 4 } Nondelisted & Count $(n)$ & 115 & High \\
& $\%$ & $82.7 \%$ & $17.3 \%$ \\
\multirow{2}{*}{ Delisted } & Count & 106 & 33 \\
& $\%(n)$ & $76.3 \%$ & $23.7 \%$ \\
\hline
\end{tabular}




\subsection{Methodology}

We follow the methodology of Doidge et al. (2009), Hansen et al. (2009), and Piotroski and Srinivasan (2008) and apply a logistic regression model to compare the non-delisted and delisted ADR firms. The statistical model used to test the hypotheses follows:

$$
\begin{gathered}
\operatorname{Prob}(\text { DELIST })=\beta_{0}+\beta_{\text {lprofitability }+} \beta_{2} \text { firm size }+\beta_{3} \text { corporate governance }+\beta_{4} \text { leverage }+ \\
\beta_{5} \text { SOX legislation }+\varepsilon,
\end{gathered}
$$

where

ADR listing status (DELIST) is a categorical dependent variable with categories coded as either non-delisted international firm with a code of 0 or delisted international firm with a code of 1 . Data on this variable is obtained from the Bank of New York Mellon, SEC, and CRSP database.

Profitability is computed as net income divided by total assets. We use sum of the total of current assets; property, plants, and equipment; long-term investments; and other assets, as total assets. As proposed in hypothesis 2, an inverse relationship is expected between profitability and the probability of delisting.

Firm size: We use total assets, defined above, as a proxy for firm size. As suggested in hypothesis 3, an inverse relation between the probability of delisting and firm size is expected.

Corporate governance: We use audit quality as a proxy for corporate governance. This variable is a dichotomous one. Consequently we ascribed a code of 1 if a firm uses high-quality audit services and 0 if it uses low-quality audit services. Quality of the audit services is assessed based on the size of the audit firm. According to Piotroski and Srinivasan (2008), the Big five firms consisted of Arthur Andersen, Deloitte and Touche, Ernst \& Young, PricewaterhouseCoopers, and KPMG, which represents high-quality audit services; the non-Big five firms represent low-quality audit services. Data on this variable is obtained from the Mergent Online database and SEC database. As noted in hypothesis 4 , an inverse relationship between audit quality and the probability of delisting is expected.

Leverage: The ratio of total debt to total assets is used as a proxy for leverage. This variable measures the extent to which the assets of a firm can decline in value before the liabilities exceed the assets and the firm becomes insolvent (Gibson, 2011). This ratio is obtained from the balance sheet of each international firm. The information was retrieved from the Mergent Online database and SEC database.

SOX Legislation: This dummy variable is a categorical (dichotomous) variable with categories coded as either pre-SOX or post-SOX time period of firm listing status. The information is retrieved from the Bank of New York Mellon and CRSP database. The period after the passage of the SOX legislation (post-SOX; 2002-2007) is ascribed a code of 1 and the time period prior to the passage of SOX legislation (pre-SOX; 1997-2001) is ascribed a code of 0. A direct relationship between SOX legislation and the probability of delisting was expected.

\section{Empirical Results}

To test hypothesis 1 , which is to determine the relationship between probability of delisting by international firms and the 2002 SOX legislation, we utilize chi-square analysis. (Note 3) In Table 4, both pre-SOX and post-SOX entries are represented by percentages of 69.5 , indicating independence, the expected frequencies are greater than 1 , and not more than $20 \%$ of the expected frequencies are less than 5 . (Note 4 ) These data support all the assumptions for chi-square analysis. In addition, the chi-square of $\chi^{2}(1, n=139)=76.3, p<.05$ indicates there is a significant difference in the number of international firms that voluntarily delisted after the passage of SOX legislation (121 of the 139 international firms), compared to those that voluntarily delisted before the passage of SOX legislation (18 of the 139 international firms).

This result depicts a higher percentage of international firms that voluntarily delisted after the SOX legislation (87.1\%) than international firms that voluntarily delisted before the passage of SOX legislation (12.9\%). This represents an increase of $74.2 \%$ in the number of voluntary delisting following the passage of SOX. Consistent with the study expectations, ADR listing status is positively associated with the passage of the SOX legislation. In other words the passage of SOX is associated with more international firms delisting from U. S. exchanges. 
Table 4. Chi Square goodness-of-fit for delisted ADR listing status by SOX legislation

The chi-square analysis classifies the distribution of voluntary delisted international firms between the pre-SOX (1997-2001) and post-SOX (2002-2007) periods.

\begin{tabular}{lccc}
\hline SOX & Observed & $\%$ & Expected \\
\hline Pre- & 18 & 12.9 & 69.5 \\
Post- & 121 & 87.1 & 69.5 \\
Total & 139 & 100 & 139.0
\end{tabular}

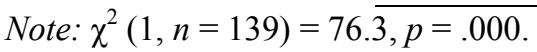

To test hypotheses 2 through 5, we run a logistical regression model. The results of the four-variable logistical regression model predicting ADR listing status based on the selected variables discussed earlier are presented in Table 5 (Note 5). First, at each step, chi-square analysis is used to determine if the model with the variables included is significant. Second, the Wald test is applied to determine the predictive value of each of the coefficients in the model. This test is performed for the coefficient of each independent variable to test if that coefficient is statistically significant.

Table 5. Hierarchical regression analysis for variables predicting ADR listing status

First, a logistic regression is run with profitability ratio. Second, while retaining profitability ratio, firm size was introduced then dropped after the analysis revealed it was insignificant. Third, profitability ratio and corporate governance were introduced into the model. Corporate governance was found to be insignificant. Lastly, leverage ratio was introduced into the model while retaining profitability ratio.

\begin{tabular}{lcccc}
\hline Variable & $B$ & Wald & $d f$ & $p^{*}$ \\
\hline Step $1 \chi^{2}(1, n=278)=21.60, p=.000$ & & & & \\
$\quad$ Profitability & $-2.71^{* *}$ & 13.87 & 1 & .000 \\
Step $2 \chi^{2}(2, n=278)=27.15, p=.000$ & & & & \\
$\quad$ Profitability & $-2.65^{* *}$ & 13.07 & 1 & .000 \\
$\quad$ Size & $-8,92 \mathrm{E}-10$ & 2.07 & 1 & .151 \\
Step $3(2, n=278)=23.40, p=.000$ & & & & \\
$\quad$ Profitability & $-2.72^{* *}$ & 14.09 & 1 & .000 \\
$\quad$ Governance & -.41 & 1.79 & 1 & .182 \\
Step $4(3, n=278)=28.77, p=.000$ & & & & .000 \\
$\quad$ Profitability & $-2.56^{* *}$ & 12.45 & 1 & .209 \\
$\quad$ Leverage & .56 & 158 & 1 &
\end{tabular}

Note: Step 1 Nagelkerke $R^{2}=.10$. Step 2 Nagelkerke $R^{2}=.12$. Step 3 Nagelkerke $R^{2}=.11$. Step 4 Nagelkerke $R^{2}$ $=.10$.

$* p<.05 . * * p<.01$

Next, Nagelkerke $R^{2}$ (an approximation of $\mathrm{R}^{2}$ used in logistic regressions) is examined at each step to determine the $R^{2}$ (explained variability of ADR status increased). If the Wald test is insignificant and $R^{2}$ does not increase more than $3 \%$, the variable is not included in the next step of the modeling process. The best result would be the highest level of coefficient of determination $\left(\mathrm{R}^{2}\right)$ using the least number of independent variables by revealing the variability in predicting ADR listing status from the NYSE and/or NASDAQ. The independent variables are introduced into the model and removed to achieve the maximum level of model reliability using the least number of variables.

First, we introduce profitability ratio into the model. The Wald test reveals the estimate of the coefficient of profitability ratio on the logistical regression model is significantly different from zero, indicating that yearly profitability contributes to the prediction of ADR listing status $\left(\chi^{2}(1, n=278)=21.60, p<.01\right)$. The negative 
coefficient $(B=-2.71)$ reveals that lower profitability is associated with higher ADR delisting, and is consistent with our second hypothesis. Results of the Nagelkerke $R^{2}$ regarding the profitability ratio show the model explains $10 \%$ of the variability in ADR listing status.

Second, the independent variables of profitability ratio and firm size are introduced into the model. The Wald test reveals the estimates of the coefficients of yearly profitability ratio and firm size on the logistical regression model are significantly different from zero, indicating that profitability and firm size contribute to the prediction of ADR listing status $\left(\chi^{2}(1, n=278)=27.15, p<.01\right)$. The coefficient on the firm size variable has the expected sign (and is consistent with our third hypothesis), but not significant. The Wald test indicates profitability ratio still contributes to the prediction of ADR listing status at $p<.01$. However, the Wald test indicates firm size does not significantly contribute to the prediction of ADR listing status. Results of the Nagelkerke $R^{2}$ regarding the yearly profitability ratio and firm size show the model explains $12 \%$ of the variability in ADR listing status, an increase over the first model by $2 \%$ but less than the desired $3 \%$ increase. Therefore, firm size is not retained in the model.

Third, the independent variables of yearly profitability ratio and corporate governance are introduced into the model. The Wald test reveals the estimates of the coefficients for yearly profitability ratio and corporate governance on the logistical regression model are significantly different from zero, indicating that profitability ratio and corporate governance contribute to the prediction of ADR listing status $\left(\chi^{2}(1, n=278)=23.40, p<.01\right)$. The coefficient on the corporate governance variable has the expected sign (and is consistent with our fourth hypothesis), but insignificant. The Wald test for the yearly profitability ratio continues to contribute to the prediction of ADR listing status. However, the Wald test indicates corporate governance does not significantly contribute to the prediction of ADR listing status. Results of the Nagelkerke $R^{2}$ regarding the yearly profitability ratio and corporate governance show the model explains $11 \%$ of the variability in ADR listing status, an increase over the first model by $1 \%$ but less than the desired 3\% increase. Therefore, we excluded corporate governance from the model.

Lastly, yearly profitability ratio and leverage ratio are introduced into the model. The Wald test reveals the estimates of the coefficients of yearly profitability ratio and leverage ratio on the logistical regression model are significantly different from zero, indicating that profitability and leverage contribute to the prediction of ADR listing status $\left(\chi^{2}(1\right.$, $n=278)=28.77, p<.01$ ). The coefficient on leverage has the expected sign (and is consistent with our fifth hypothesis), but not significant. The Wald test reveals that the profitability ratio consistently adds to the prediction of ADR listing status at $p<.01$. However, the Wald test indicates leverage ratio does not significantly contribute to the prediction of ADR listing status. Results of the Nagelkerke $R^{2}$ regarding the yearly profitability ratio and leverage ratio show the model explains $10 \%$ of the variability in ADR listing status, no increase over the first model and less than the desired $3 \%$ increase. Therefore, leverage ratio is not retained in the model.

The Wald test reveals that estimates of the coefficients for firm size, corporate governance, and leverage ratio on the logistical regression model are not statistically significant, indicating that these independent variables do not contribute to the prediction of ADR listing status. The results show that the predictor variable, profitability ratio, is statistically significant at the $p<.01$ significance level and contributes to the prediction of ADR listing status by explaining $10 \%$ of the variability in the logistical regression model (see Table 5). The results from the logistical regression model reveal that the profitability ratio is the strongest predictor of ADR listing status, and that firm size, corporate governance, and leverage ratio are not statistically significant predictors of ADR listing status.

\section{Conclusion}

Using 278 international firms, which include 139 delisted international firms and a matched pair of 139 non-delisted international firms, we find that the number of voluntary delisting increased from $12.9 \%$ in the pre-SOX period (1997 - 2001) to $87.1 \%$ in the post-SOX period (2002 - 2007), representing an increase of $74.2 \%$. In addition, yearly profitability ratio is negatively affected by ADR listing status and is the strongest predictor in the logistical regression model. In other words, lower profitability is associated with higher probability of delisting. Furthermore, firm size, corporate governance and leverage ratio are not statistically significant in predicting ADR listing status or associated with SOX legislation. This supports the documented evidence that SOX legislation does not decrease or negatively affect firm size, corporate governance, or leverage ratio.

The result of this study is consistent with those of Georgieva (2009) and Licht (2004) in that the implementation of SOX resulted in an increase in compliance costs thereby dissipating the bonding and signaling benefits, leading to more delisting by international firms from U.S. exchanges.

The lack of a statistically significant predictive relationship between ADR listing status and SOX legislation with regard to firm size was unexpected because the bonding theory suggests firm size influences the ability of a firm to 
increase stock valuation. The results of this study regarding firm size do not support the bonding or signaling theories. Findings from the study for leverage ratio were unexpected because according to the bonding theory, a benefit to listing on the U.S. exchange was the availability of obtaining external financing (Licht, 2004).

\section{References}

Alexander, G. J., Eun, C. S., \& Janakiramanan, S. (1988). International listings and stock returns: Some empirical evidence. Journal of Financial and Quantitative Analysis, 23, 135-151. http://dx.doi.org/10.2307/2330877

Anand, S., \& Tarantino, A. (2010). Sarbanes Oxley in leading economies. Upper Saddle River, NJ: Pearson Prentice Hall.

Asthana, S., Balsam, S., \& Kim, S. (2009). The effect of Enron, Andersen, and Sarbanes-Oxley on the US market for audit services. Accounting Research Journal, 22, 4-26. http://dx.doi.org/10.1108/10309610910975306

Bank of New York Mellon. (n.d.). DR directory. Retrieved October 23, 2013, from http://www.adrbnymellon.com/dr_directory.jsp

Block, S. B. (2004). The latest movement to going private: An empirical study. Journal of Applied Finance, 14(1), 3644. Retrieved from http://www.fma.org/Publications/JAF/JAFIndex.htm

Brealey, R., Leland, H. E., \& Pyle, D. H. (1977). Informational asymmetries, financial structure, and financial intermediation. Journal of Finance, 32, 371-387. http://dx.doi.org/10.1111/j.1540-6261.1977.tb03277.x

Cárdenas, E. J. (2009). Mexican corporations entering and leaving U.S. markets: An impact of the Sarbanes-Oxley Act of 2002? Connecticut Journal of International Law, 23, 281-368. Retrieved from http://www.law.uconn.edu/connecticut-journal-international-law/

Chen, K. H., \& Shimerda, T. A. (1981). An empirical analysis of useful financial ratios. Financial Management, 2, 5160. Retrieved from http://onlinelibrary.wiley.com/journal/10.1111/(ISSN)1755-053X

Coffee, J. C., Jr. (1999). The future as history: The prospects for global convergence in corporate governance and its implications. Northwestern University Law Review, 93, 641-708. Retrieved from http://www.law.northwestern.edu/journals/lawreview/

Doidge, C., Karolyi, G. A., \& Stulz, R. M. (2004). Why are foreign firms listed in the U.S. worth more? Journal of Financial Economics, 71, 205-238. http://dx.doi.org/10.1016/S0304-405X(03)00183-1

Doidge, C., Karolyi, G. A., \& Stulz, R. M. (2009). Has New York become less competitive than London in global markets? Evaluating foreign listing choices over time. Journal of Financial Economics, 91, 253-277. http://dx.doi.org/10.1016/j.jfineco.2008.02.010

Doidge, C., Karolyi, G. A., \& Stulz, R. M. (2010). Why do foreign firms leave U.S. equity markets? Journal of Finance, 65, 1507-1553. http://dx.doi.org/10.1111/j.1540-6261.2010.01577.x

Fernandes, N., Lel, U., \& Miller, D. P. (2010). Escape from New York: The market impact of loosening disclosure requirements. Journal of Financial Economics, 95, 129-147. http://dx.doi.org/10.1016/j.jfineco.2008.12.010

Georgieva, D. (2009). Does Sarbanes-Oxley Act chase away foreign firms? Evidence from ADR terminations. Journal of International Business Research, 8(2), 115-128. Retrieved from http://www.alliedacademies.org/public/journals/journaldetails.aspx?jid=15

Gibson, C. H. (2011). Financial reporting \& analysis: Using financial accounting information (12th ed.). Mason, OH: South-Western Cengage.

Gleason, K., Payne, B., \& Wiggenhorn, J. (2007). An empirical investigation of going private decisions of U.S. firms. Journal of Economics and Finance, 31, 207-218. http://dx.doi.org/10.1007/BF02751643

Hansen, B., Pownall, G., \& Wang, X. (2009). The robustness of the Sarbanes Oxley effect on the U.S. capital market. Review of Accounting Studies, 14, 401-439. http://dx.doi.org/10.1007/s11142-009-9094-7

Holmstrom, B., \& Kaplan, S. N. (2003). The state of U.S. corporate governance: What's right and what's wrong? Journal of Applied Corporate Finance, 15(3), 7-20. http://dx.doi.org/10.1111/j.1745-6622.2003.tb00457.x

Huang, R. D., \& Stoll, H. R. (1996). Dealer versus auction markets: A paired comparison of executive costs on NASDAQ and the NYSE. Journal of Financial Economics, 41, 313-357. http://dx.doi.org/10.1016/0304-405X(95)00867-E

Karolyi, G. A. (1998). Why do companies list abroad?: A survey of the evidence and its managerial implications. Financial Markets, Institutions \& Instruments, 7(1), 1-60. http://dx.doi.org/10.1111/1468-0416.00018 
Krishnan, J., Rama, D., \& Zhang, Y. (2008). Costs to comply with SOX Section 404. Auditing: A Journal of Practice \& Theory, 27(1), 169-186. http://dx.doi.org/10.2308/aud.2008.27.1.169

Lang, M. H., Lins, K. V., \& Miller, D. P. (2003). ADRs, analysts, and accuracy: Does cross listing in the U.S. improve a firm's information environment and increase market value? Journal of Accounting Research, 41, 317-345. http://dx.doi.org/10.1111/1475-679X.00106

Licht, A. N. (2004). Cross-listing and corporate governance: Bonding or avoiding? Corporate Ownership and Control, 1(4), 36-48. Retrieved from http://www.virtusinterpress.org/-Corporate-Ownership-and-Control-html

Linck, J. S., Netter, J. M., \& Yang, T. (2009). The effects and unintended consequences of the Sarbanes-Oxley Act on the supply and demand for directors. Review of Financial Studies, 22, 3287-3328. http://dx.doi.org/10.1093/rfs/hhn084

Litvak, K. (2007). The effect of the Sarbanes-Oxley Act on non-U.S. companies cross-listed in the U.S. Journal of Corporate Finance, 13, 195-228. http://dx.doi.org/10.1016/j.jcorpfin.2007.03.002

Nordberg, D. (2008). Waste makes haste: Sarbanes-Oxley, competitiveness and the subprime crisis. Journal of Financial Regulation and Compliance, 16, 365-383. http://dx.doi.org/10.1108/13581980810918422

Piotroski, J. D., \& Srinivasan, S. (2008). Regulation and bonding: The Sarbanes-Oxley act and the flow of international listings. Journal of Accounting Research, 46, 383-425. http://dx.doi.org/10.1111/j.1475-679X.2008.00279.x

Saudagaran, S. M. (1988). An empirical study of selected factors influencing the decision to list on foreign stock exchanges. Journal of International Business Studies, 19, 101-127. http://dx.doi.org/10.1057/palgrave.jibs. 8490377

Szafran, R. F. (2011). Answering questions with statistics. Thousand Oaks, CA: Sage.

Ule, G. M. (1937). Price movements of newly listed common stock. Journal of Business of the University of Chicago, 10, 346-369. http://dx.doi.org/10.1086/232469

U.S. Securities and Exchange Commission (SEC). (n.d.). EDGAR search for company filings. Retrieved June 23, 2013, from http://www.sec.gov/edgar/searchedgar/companysearch.html

U.S. Securities and Exchange Commission (SEC). (2007). Foreign companies registered and reporting with the U.S. Securities and Exchange Commission. Retrieved from $\mathrm{http}: / /$ www.sec.gov/divisions/corpfin/internatl/foreigngeographic2007.pdf

Vogt, W. P. (2007). Quantitative research methods for professionals. Boston, MA: Pearson.

Wahlen, J. M., Stickney, C. P., Brown, P., Baginski, S. P., \& Bradshaw, M. (2011). Financial reporting, financial statement analysis, and valuation: A strategic perspective (7th ed.). Mason, $\mathrm{OH}$ : Cengage.

Ying, L. K. W., Lewellen, W. G., Schlarbaum, G. C., \& Lease, R. C. (1977). Stock exchange listings and securities returns. Journal of Financial and Quantitative Analysis, 12, 415-432. http://dx.doi.org/10.2307/2330543

Zhang, I. X. (2007). Economic consequences of the Sarbanes-Oxley act of 2002. Journal of Accounting and Economics, 44, 74-115. http://dx.doi.org/10.1016/j.jacceco.2007.02.002

\section{Notes}

Note 1. SOX compliance causes listed firms to incur additional costs that include fees paid for independent audits of internal controls over financial reporting (a newly imposed requirement by SOX), fees paid to outside vendors, increased staff hours spent for compliance, and nonrelated technological expenses of software and hardware (Cárdenas, 2009; Krishnan et al., 2008; I. X. Zhang, 2007).

Note 2. Levels II and III ADRs list and trade on the U.S. stock exchanges and must comply with SOX regulation.

Note 3. According to Vogt (2007), chi-square analysis does not require the variables to be normally distributed or measured on an interval scale; instead, the analysis requires the ability to classify the variables into a set of categories (i.e., nominal measurement).

Note 4. According to Szafran (2011), for the results to be valid, the variables must have independence, i.e. the expected frequencies must be greater than or equal to 1 , but less than or equal to $20 \%$.

Note 5. Test for multicollinearity of the independent variables using preliminary multiple regression analysis indicates none of the independent variables is highly correlated. 